\title{
【㳍田琴次先生古稀記念論文】
}

\section{ICHIHARA, M.D.: ON THE FINDINGS OF NASAL CAVITY OF ASTHMA BRONCHIALE}

\section{気管支喘息患者の鼻腔所見に就て}

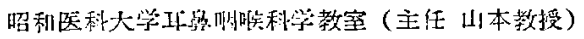

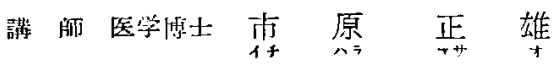

緒言

アレルギーに関寸る不究は洋の東西を問わす数多

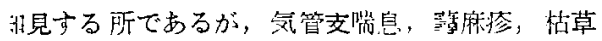
泪, タインケ氏浮腫, 血管運動神経性鼻多等はアレ レギー学説の隆盛なるに及び，己等は夫ふ独むせる

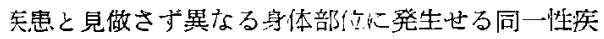
寻と見䍀され，之等は総合的研究に问 5 傾向があ 3 .

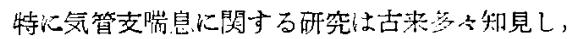
基の数を挙げ得ざる程の状態である。

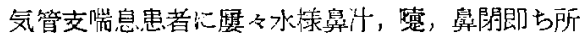
胃血管運動神経性参炎の症状を呈することは之不，

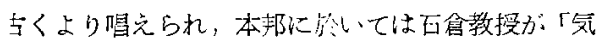
等支䍀息总旨の鼻腔所見についてて」詳稩な報告を行 つているが，余も亦，気管支嵒自患者の鼻所見走检 したので，茲に報告し，諸彥の御批判を气わんとす るものである。

\section{実験材料並に実駼成程}

材料は昭和 21 年 10 月より硈和 22 年9月至方 F烡大学叫山外科入院患者 100 例て古方.

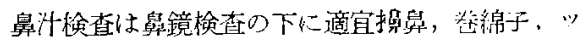
シルタリン注射器にて粘膜面に拉蜰することを澼

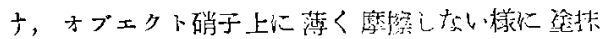
し，空泚て乾燥，固定するか或はメチールアルコ ールて固定し. Pappenheim 氏 May-Gimsa-Kom-

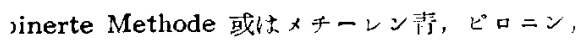
メチールグリスーン染色法を行つた。

\section{央験成緄}

鼻内所見は第 1 表の如く $9-37$
第 1 表

\begin{tabular}{|c|c|}
\hline 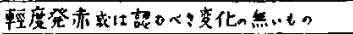 & 27 例 \\
\hline 荅白浮腫狀民呈才了切 & 4251 \\
\hline 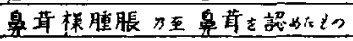 & 16 19 \\
\hline 滕性鼻汁著明の次 & 641 \\
\hline 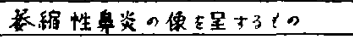 & 94 誃 \\
\hline 説 & $1001 \times 1$ \\
\hline
\end{tabular}

鼻の汁性状は第 2 萃の通りて

\begin{tabular}{|c|c|}
\hline 第 & 表 \\
\hline 液 性 & 58 晌 \\
\hline 呫 济 性 & 18 401 \\
\hline 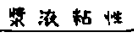 & 18 的 \\
\hline 脿 位 & 6 㫋 \\
\hline 計 & 100 列 \\
\hline
\end{tabular}

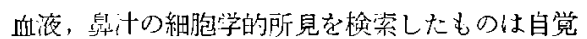

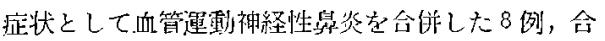

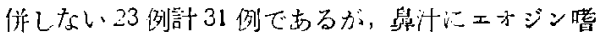

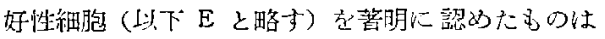
第3表の通りである。

\begin{tabular}{|c|r|}
\multicolumn{1}{c}{ 第 } & 3 表 \\
\hline$E(+)$ & 26 例 $(83.9 \%)$ \\
\hline$E(-)$ & 5 例 $(16.1 \%)$ \\
\hline
\end{tabular}

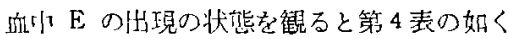

\begin{tabular}{|c|c|}
\hline 第 & 表 \\
\hline $0 \sim 4 \%$ & 7 例 $(222 \%)$ \\
\hline $5 \sim 9 \%$ & $14+11(45.2 \%)$ \\
\hline $10 \sim 14 \%$ & 6 例 $(19.4 \%)$ \\
\hline $15 \% \mathrm{mt}$ & 4 例 $(13.2 \%)$ \\
\hline 言† & 31 制 $(100 \%)$ \\
\hline
\end{tabular}

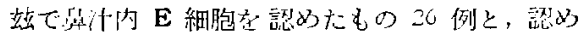


得ない５测の鼻汁の性状を篗ると第５表の通りで ある。

\begin{tabular}{|c|c|c|c|c|c|c|}
\hline \multirow{5}{*}{$E(+)$} & \multirow{5}{*}{ 帛: } & 装泳性 & 19 |g|l| & $(3.996)$ & 0 纱 (0:) & \multirow{5}{*}{$\overline{E(-)}$} \\
\hline & & 鈢疗性 & 5 例 & $(19 \%)$ & 0 (का $(0 \%)$ & \\
\hline & & 象，粘，性 & 2 例 & $(8 \%)$ & $I$ 例 $(20 \%)$ & \\
\hline & & 恉 性 & 0 例 & $(0 \%)$ & 4 敝 $(80 \%)$ & \\
\hline & & $\mathbf{t}^{+}$ & 26 例 & $(100 \%)$ & 5 例 (100\%) & \\
\hline
\end{tabular}

又，身汁内 $\mathrm{E}$ を認めたもの，認め得ないもの」

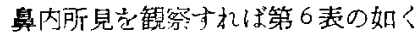

\begin{tabular}{|c|c|c|c|c|}
\hline \multirow{6}{*}{$E(+)$} & 重知譄 & 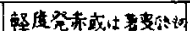 & 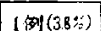 & \multirow{2}{*}{1 制(20\%) } \\
\hline & & 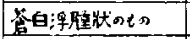 & $19601(73)$ & \\
\hline & & 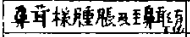 & 6m(23.1\%) & 0 例 $(0 \%)$ \\
\hline & & 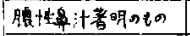 & 0 例 $(0 \%)$ & 3 唡 $(60 \%)$ \\
\hline & & 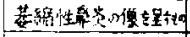 & 0 例 $(0 \%)$ & 1 例 (20\%) \\
\hline & & th & 26 㸮 $1(00 \%$ & 5 络 $(100 \% \%$ \\
\hline
\end{tabular}

鼠讨内 $\mathrm{E}$ と舅叫 $\mathrm{E}$ との関保は第》表の通りで ある。

\begin{tabular}{|c|c|c|c|c|c|}
\hline \multirow{5}{*}{$E(+)$} & \multirow{5}{*}{ 血中E } & & & & \multirow{5}{*}{$\overrightarrow{E(-)}$} \\
\hline & & $5 \sim 9 \%$ & 13 例 $(50 \%)$ & $100 \%$ & \\
\hline & & $10 \sim 14 \%$ & 8 例 $(30.8 \%)$ & 1 例 $(20 \%)$ & \\
\hline & & $15 \%$ wex & 2 伍 $(7.7 \%)$ & 1 例 $(20 \%)$ & \\
\hline & & 計 & 26 例 $(190 \%)$ & 5 例 $(100 \%)$ & \\
\hline
\end{tabular}

\section{総括並に考按}

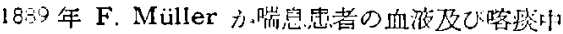
にE 增多むる登颇告して以来諸氏の追試する所と なつたが,

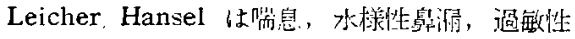

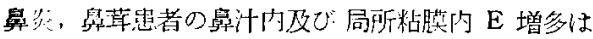

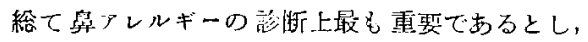

Ball は喘息急者の9 例の舁腔及び副鼻腔の病理組

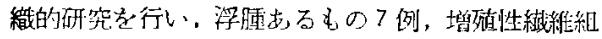

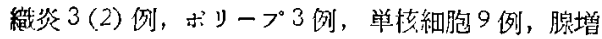
殖 2 例孝挙计, E. 9 (8) 例案認好, Fink, Hansel

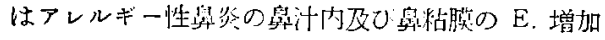

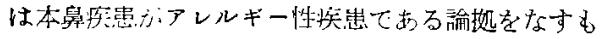
のとし，Eyermannはアレルギー性鼻炎患者の禹

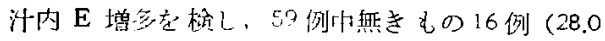
\%)を举けている。
藤沢圷はアレルギー性鼻炎患者の㰾汗内 E. 增多

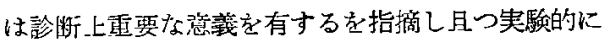
海䐎に舅粘㬴の局所過敏症を発来せしめた。

又伊藤，上村氏は鼻汁内 $\mathrm{E}$. 增加はアレルギー性 鼻炎に特異的であるとし，高橋氏は鼻アレルギ一患 者 72 例中 65 例他 E. 増多を認めている。

石倉教授は気管枝喘息患者 68 名の鼻腔所見に就 て，鼻内分泌物に就ては等夜性又は粘液性なるもの

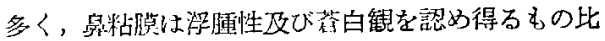
較的多く，夫れ等の中明らかに血管運動神経性鼻炎

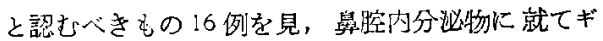

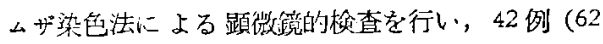

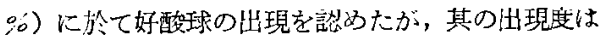

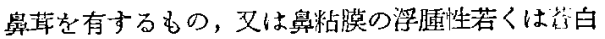
観を示扵症例に多く，鼠粘膜の变化泛しき症例に於 ては㱠んど其の出現を諗好，血液蚞查の結果 27 例 $(40 \%$ ） に於て血液内好酸球 $4 \%$ 以上の数値を認 めただ，アレルギー閣与率と思われる10\%以上に 及ら゙もの12 例 (18\%) であつた。とし，

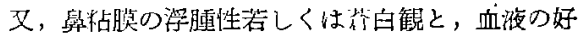

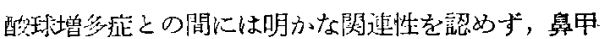
介にアドレナリンを徝布して其の収縮底を観察した

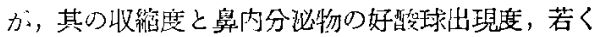

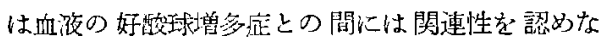
い.と報告している.

翻つて余の成縜を错ると，気管支喘息患者 100 例 中，鼠所見は符白浮嗹状を呈するむの最も多く 42 例飞して，石含氏の成績々一致し，累内分必物

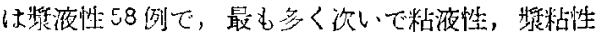
各 13 例にして，之文，间氏の成緼に合致している。

荈内分汹物に就ての余の成結は 31 例的，26 例 (83.9\%)にE. 增多を热めたが，氏の成綪は68 例

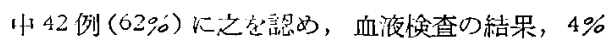

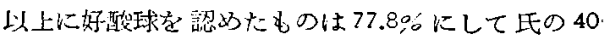
$\%$ 上り滛か儿高泽に見ら机，10\%以上の屯のは 32.6 $\%$ で，同氐の18\%に比すれば同じく高率を示して いる。

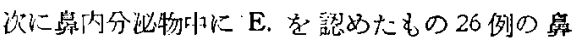
汁，鼻粘荧の性状に就いて見ると，舅汁の性状は漿

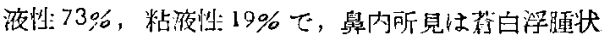
$73.1 \%$ にして最も名く，之は諸氏の成縙と息く一致 
ててろ.

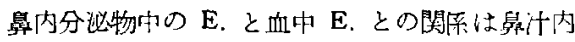

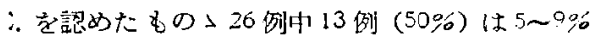
こ血小 E. を見た。

又，気管支喘息発作前，小，後に籍等した了例の 績上りす妃ば血中 $\mathrm{E}$ ，細胞出現は鼻汁中出現に先 しじて出現しており，之は山中上が約弱海猽を用い

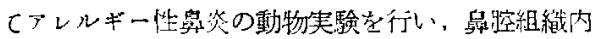
尽化は血液に方活る变化と共に始り，其の組織内成 子より見てる略た平行した曲線をなすが，流血小变 七が常に一步先んじて現れる事を認る，血液像に花 つて畕腔組織内の大要它窥知し得られるもの入如し 上している，との塞験と比較して與味がある。

之を要するに気導アレルギー性疾患の鼻汁及び喀 芜中の顕微鏡的所見はアレルギー性疾患の磪誩にな ろとは云えないまでも諺断上重要な一因子であると 思れる。

\section{結 論}

1）気管支㟨息患者 100 例の 鼻内所見は軽度発赤

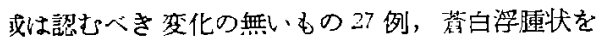

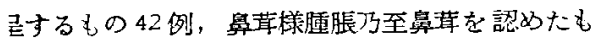
つ15 例等であつた。

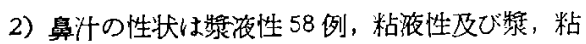
夜性各18例，胀性6例であつた。

3）鼻汁内 E. 細胞を諗めたものは26例 (83.9\%)， 忍めないすの 5 例 $(16.1 \%$ ) であつた。

4) 血中 E. は $0 \sim 4 \%, 7$ 例 $(22.2 \%)$. 5 - 9\%, 14 列 $(45.2 \%) ， 10 \sim 14 \% ， 6$ 的 $(19.4 \%)$. 15\%以上, !例(13.2\%)であつた。

5）鼻汁内 E。を諗めた26例の鼻什の性状は槳液

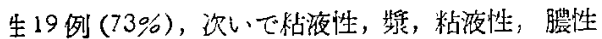
つ順で，E，を認めない５例师，澧性は 4例 (80\%) であつた。

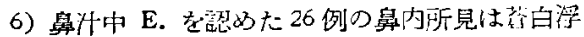

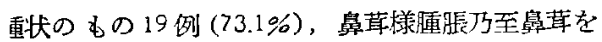
与する8の6例 $(23.1 \%)$ で，E．を認めない５例中 例 (60\%) 憹性舅汁著明のものであつた。

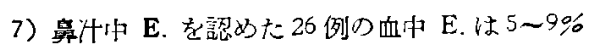
3 例 (50\%)，10 14\%8例 (30.8\%)にして，E.を

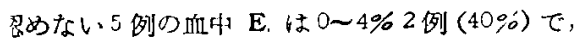

5〜9\%, 10〜 14\%, $15 \%$ 以上は夫子1例 (20\%) て あつた。

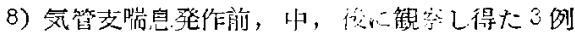

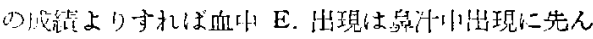
じて出現していた。

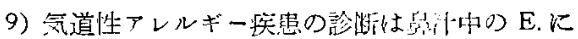

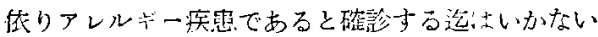
までも猃断、上重要な一因于であると思装する。

\section{文献}

1) Eyermann: Ann. of O, R. L., 36, p. 808, 1927. 2) Hansel: J. A. M. A., Vol. 62, p. 15, 1924. 3) Hansel: J. Allergy, Vol. 1, p. 43, 1929. 4) Hansel: Ann. of Otology., Vol. 39, 1930. 5) Hansel: J. Allergy, Vol. 5, No. 4, p. $357,1934 . \quad$ 6) Hansel: Ann. of O. R. L. 49, p. 54, p. 359,1940, 7) 藤沢: 日臣, 42

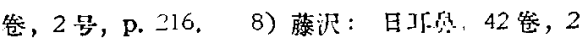

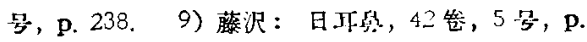
645, 10) 市原：アレルギーを踪林 (文光堂)。

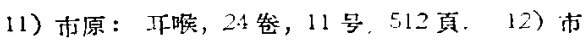

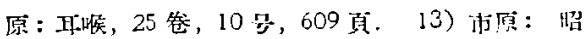

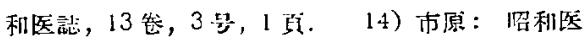

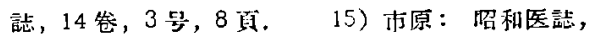

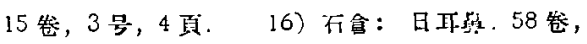

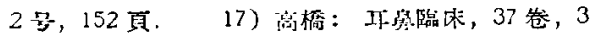

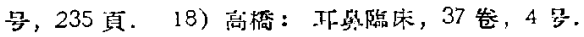
340 真. 19) 分目：日年多，38卷，7少，86

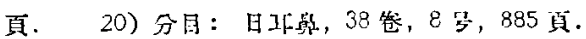

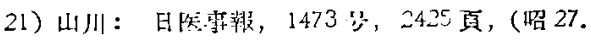
$7.19)$.

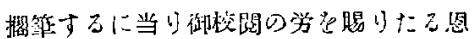

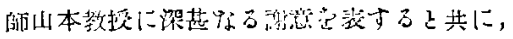

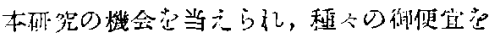

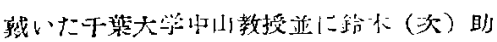

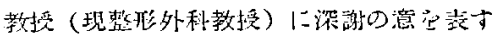

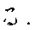

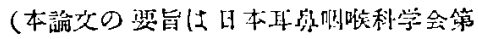
333 回東京地方会に於て演连した）。

（原稳到莧二昭利30.11.22日） 